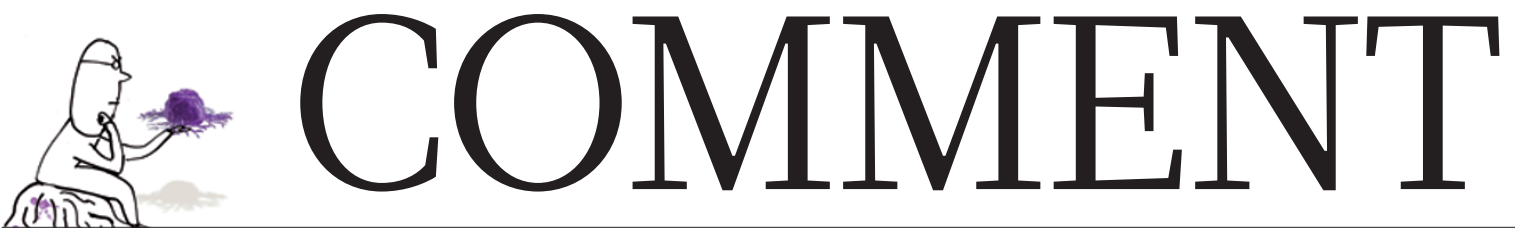

FUNDING Asking the right questions can revitalize research $\mathbf{p . 4 3 6}$
BIOGRAPHY Joseph Rotblat's crusade for nuclear disarmament $\mathbf{p . 4 3 8}$
COSMOLOGY How to create the Universe from a sea of nothing $\mathbf{p . 4 4 0}$
OBITUARY James Crow, genetic pioneer and accomplished musician $\mathbf{p . 4 4 4}$

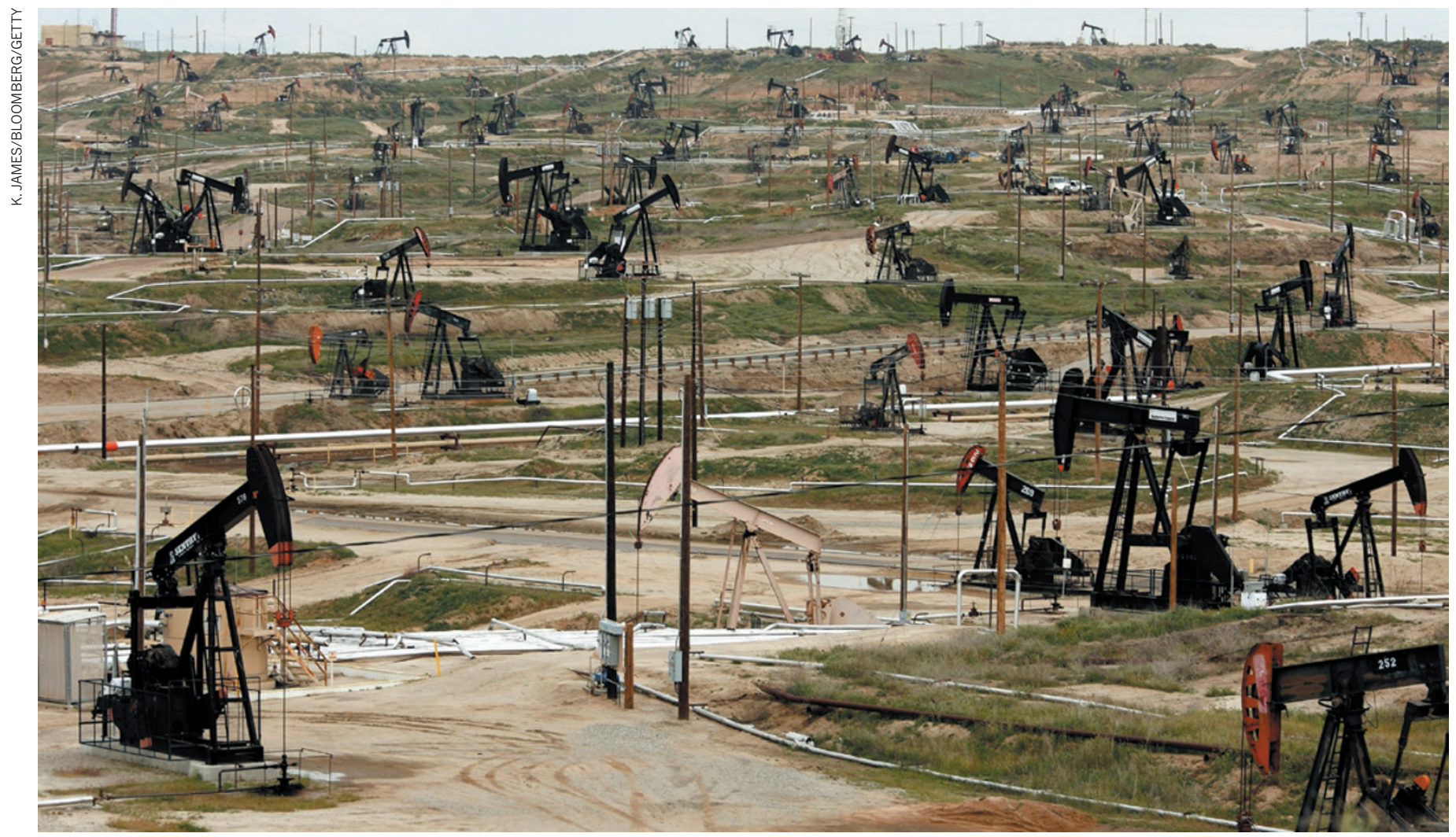

Production at oil fields globally, including at the Kern River oil field in Bakersfield, California, is declining at about 4-6\% a year.

\title{
Oil's tipping point has passed
}

The economic pain of a flattening supply will trump the environment as a reason to curb the use of fossil fuels, say James Murray and David King.

$\mathrm{I}$ n many parts of the world, particularly the United States, continuing debates about the quality of climate-change science and doubts about the scale of negative environmental impacts have held back political action against rising greenhousegas emissions. But there is a potentially more persuasive argument for lowering global emissions: the impact of dwindling oil supplies on the economy.

There is less fossil-fuel production available to us than many people believe. From 2005 onwards, conventional crude-oil production has not risen to match increasing demand. We argue that the oil market has tipped into a new state, similar to a phase transition in physics: production is now 'inelastic', unable to respond to rising demand, and this is leading to wild price swings. Other fossil-fuel resources don't seem capable of making up the difference.

Such major spikes in fuel price can cause economic crises, and contributed to the one the world is recovering from now. The future economy is unlikely to be able to bear what oil prices have in store. Only by moving away from fossil fuels can we both ensure a more robust economic outlook and address the challenges of climate change. This will be a decades-long transformation ${ }^{1}$ that needs to start immediately.

Production of crude oil increased along with demand from 1988 to 2005 . But then something changed. Production has been roughly constant for the past seven years, despite an increase in price of around 15\% per year ${ }^{2}$ (at Brent crude (London) prices) from about US\$15 per barrel in 1998 to more than $\$ 140$ per barrel in 2008 (see 'Oil production hits a ceiling'). The price still reflects demand: it declined to about $\$ 35$ per barrel in 2009 thanks to the 2008-09 recession, and recovered along with the upturn in the global economy to $\$ 120$ per barrel before declining to its value today of $\$ 111$. But 
the supply chain has been unable to keep pace with rising demand and prices.

The idea of 'peak oil' - that global production will reach a peak and then decline - has been around for decades, with academics arguing about whether this peak has already passed or is yet to come. The typical industry response is to point to increasing assessments of global reserves - the amount known to be in the ground that can be produced commercially. But this is misleading. The true volume of proven global reserves is clouded by secrecy; forecasts by state oil companies are not audited and seem to be exaggerated ${ }^{3}$. More importantly, reserves often take 6-10 years to drill and develop before they become part of supply, by which time older fields have become depleted. It is far more sensible to look instead at actual production records, which are less encouraging. Even while reserves are apparently increasing, the percentage available for production is going down. In the United States, for example, production as a percentage of reserves has steadily decreased from $9 \%$ in 1980 to $6 \%$ today $^{2}$. Production at existing oil fields around the world is declining at rates of about $4.5 \%$ (ref. 4 ) to $6.7 \%$ per year ${ }^{5}$. Only by adding in production from new wells is overall global production holding steady.

In 2005, global production of regular crude oil reached about 72 million barrels per day. From then on, production capacity seems to have hit a ceiling at 75 million barrels per day. A plot of prices against production from 1998 to today ${ }^{2}$ shows this dramatic transition, from a time when supply could respond elastically to rising prices caused by increased demand, to when it could not (see 'Phase shift'). As a result, prices swing wildly in response to small changes in demand. Other people have remarked on this step change in the economics of oil around the year 2005, but the point needs to be lodged more firmly in the minds of policy-makers.

\section{EASY ACCESS}

We are not running out of oil, but we are running out of oil that can be produced easily and cheaply. The US Energy Information Administration optimistically projects a 30\% increase in oil production between now and 2030 (ref. 2). All of that increase is in the form of unidentified projects - in other words, oil yet to be discovered. Even if production at existing fields miraculously stopped declining, such an increase would require 22 million barrels per day of new oil production by 2030 . If realistic declines of $5 \%$ per year continue, we would need new fields yielding more than 64 million barrels per day - roughly equivalent to today's total production. In our view, this is very unlikely to happen.

Non-conventional oil won't make up the difference. Production of oil derived from Canada's tar sands - sometimes called the

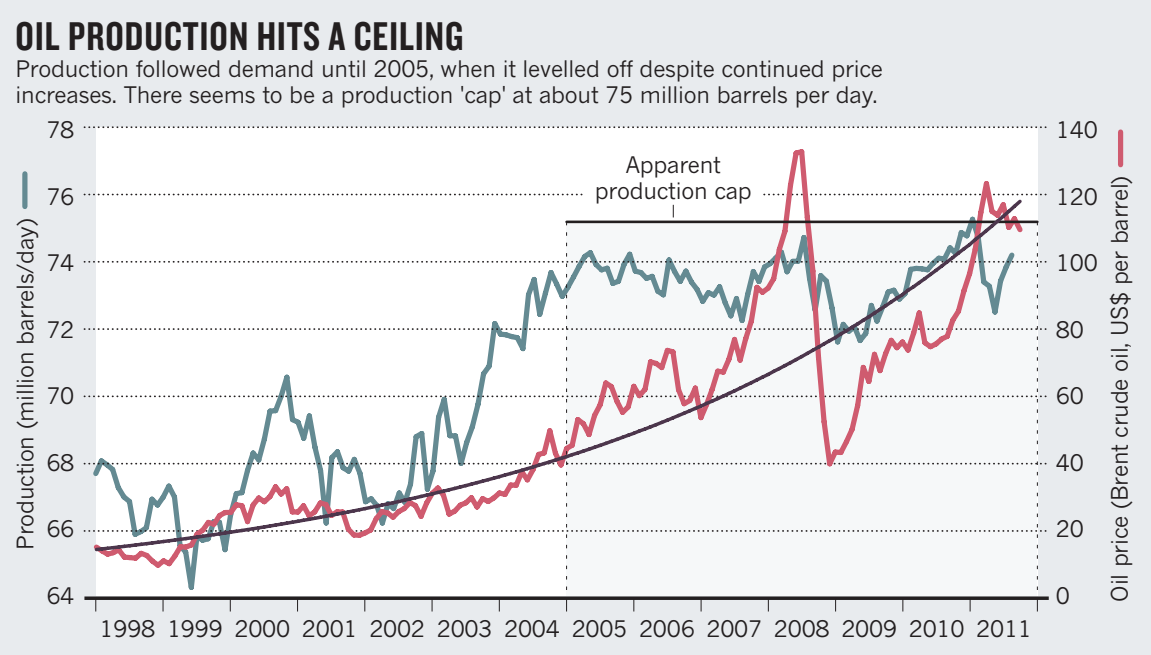

PHASE SHIFT

The abrupt change in oil economics can be seen in this scatter plot of production versus price.

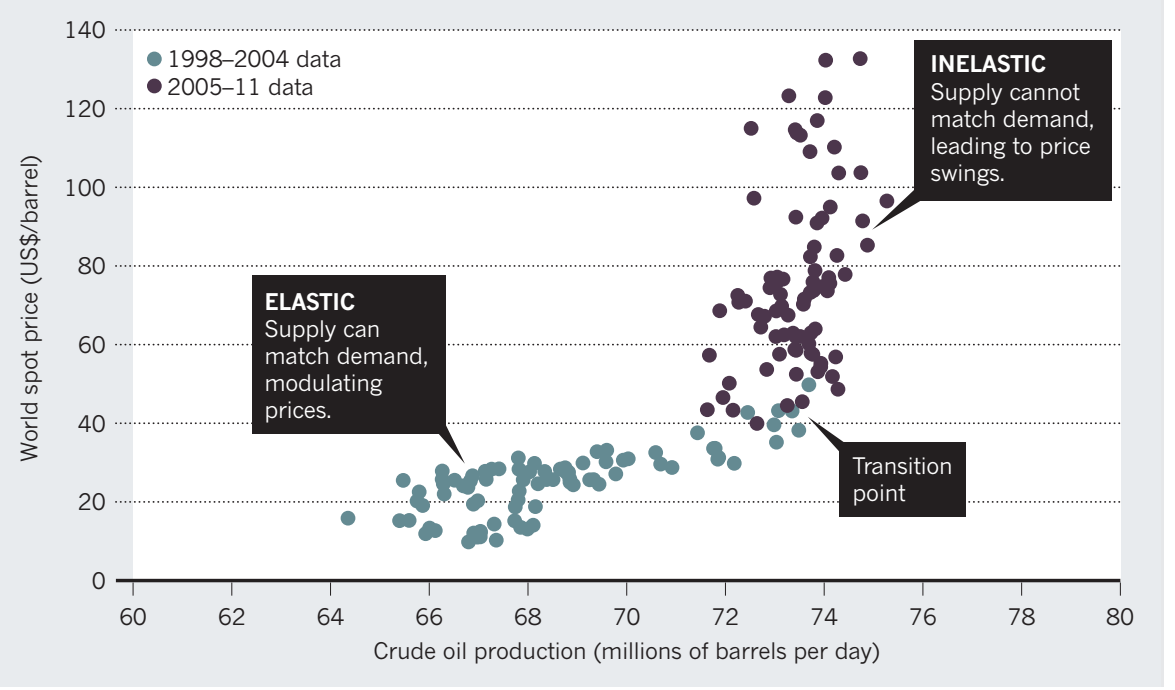

'oil junkie's last fix' - is expected to reach just 4.7 million barrels per day by 2035 (ref. 6). Production from Venezuela's tar sands is currently less than 2 million barrels per day $^{7}$, with little prospect of a dramatic increase.

Many believe that coal will be the solution to our energy needs, and will stay cheap for decades. But several recent studies suggest that available coal is less abundant than has been assumed. US coal production peaked in 2002, and world coal-energy production is projected to peak as early as 2025 (ref. 8). Whenever coal-reserve figures are updated, the estimates are usually revised downwards: estimates of world reserves ( $79 \%$ of which are held in the United States, Russia, India, China, Australia and South Africa) were decreased by more than $50 \%$ in 2005 , to 861 gigatonnes (ref. 9). That study put the ultimate production of coal (the total amount that humanity will be able to extract from the ground) at 1,163 gigatonnes. A 2011 independent estimate of ultimate production came to just 680 gigatonnes (ref. 10), some $40 \%$ lower than the 2005 figure and about five times less than assumed by some older, high-coal-consumption scenarios of the Intergovernmental Panel on Climate Change. The US National Research Council's Committee on Coal Research, Technology, and Resource Assessments to Inform Energy Policy noted in 2007 that "present estimates of coal reserves are based upon methods that have not been reviewed or revised since their inception in $1974 \ldots$ updated methods indicate that only a small fraction of previously estimated reserves are actually mineable reserves."11

Natural gas is still abundant and large discoveries have been made recently, notably in Israel and Mozambique last year. Power plants using natural gas provide $25 \%$, and rising, of electricity generation in the United States. Production of conventional natural gas in North America peaked in 2001 (ref. 2), but energy companies have worked hard to promote the idea that hydraulic fracturing of shale rock will lead to 'the age of natural gas'. There is no doubt that US shale-gas 
resources are immense, but recent reports suggest that both reserves and future production rates have been substantially overstated $^{12}$. For sites such as the Barnett and Fayetteville shales, where a long production history can be studied, there has been an extremely large annual decline in production rates. Geological consultant Arthur Berman, director of Labyrinth Consulting Services in Sugar Land, Texas, and a world expert on shale gas, has put this decline in the range of $60-90 \%$. For shale-gas wells that are more than five years old, about $30 \%$ are sub-commercial because of rapid decline combined with the low price of gas.

\section{STUNTED GROWTH}

What does this mean for the global economy, which is so closely tied to physical resources? Of the 11 recessions in the United States since the Second World War, 10, including the most recent, were preceded by a spike in oil prices ${ }^{13}$. It seems clear that it wasn't just the 'credit crunch' that triggered the 2008 recession, but the rarely-talked-about 'oilprice crunch' as well. High energy prices erode family budgets and act as a head wind against economic recovery.

The United States and Europe each spends $\$ 1$ billion per day on oil imports. The average price of petrol in the United States increased from 75 cents per litre in 2010 to 95 cents per litre in 2011. Because the United States consumes about 1.4 billion litres per day, the nation spent about $\$ 280$ million a day more on petrol in 2011, leaving less for discretionary items.

Another powerful example of the effect of increasing oil prices can be seen in Italy. In 1999 , when Italy adopted the euro, the country's annual trade surplus was $\$ 22$ billion. Since then, Italy's trade balance has altered dramatically and the country now has a deficit of $\$ 36$ billion. Although this shift has many causes, including the rise of imports from China, the increase in oil price was the most important. Despite a decrease in imports of 388,000 barrels per day compared with 1999, Italy now spends about $\$ 55$ billion a year on imported oil, up from $\$ 12$ billion in 1999. That difference is close to the current annual trade deficit. The price of oil is likely to have been a large contributor to the euro crisis in southern Europe, where countries are completely dependent on foreign oil.

The International Energy Agency has made it very clear that the global economy is at risk when oil prices are greater than $\$ 100$ per barrel - as they have been in recent years, and will surely continue to be, given the inelastic response of global production.

Historically, there has been a tight link between oil production and global economic growth. If oil production can't grow, the implication is that the economy can't grow either. This is such a frightening prospect that many have simply avoided considering it. The International Monetary Fund, for example, still projects economic growth of $4 \%$ of gross domestic product for the next five years: near the top of the historical range since 1980 . Yet to achieve that will require either a heroic increase in oil production of $3 \%$ per year, increased efficiency of oil use, more energy-efficient growth or rapid substitution of other fuel sources. Economists and politicians continually debate policies that will lead to a return to economic growth. But because they have failed to recognize that the high price of energy is a central problem, they haven't identified the necessary solution: weaning society off fossil fuel.

The UK Industry Taskforce on Peak Oil and Energy Security and the UK government's Department of Energy and Climate

"The price
of oil is likely
to have
been a large
contributor to
the euro crisis
in southern
Europe."

Change are very aware of these risks, and have made a commitment to work together to protect the United Kingdom and its economy from rising oil prices. The task force, formed in 2008, warned that Britain must not be caught out by the oil crunch, and said that policies to address 'peak oil' must be made a priority. In 2011, its chairman, John Miles of architects and design engineers Arup in London, said: "We must define the risks and develop sensible contingency plans. This means thinking critically about what we should be doing now if we knew that the oil price would soar over the next five years." Such joint industry/federal government recognition of the problem does not exist in the United States, where action has largely been at the state or city level. The UK government has embedded by parliamentary statute a commitment to decrease carbon dioxide emissions by $80 \%$ by 2050 compared with 1990 levels. The US Congress has rejected any such commitment.

\section{FASTER ACTION}

Climate change and changes in fossil-fuel production are generally seen as separate phenomena. But they are closely linked. The risk of fossil-fuel supply limitation should be included when considering the uncertainties of future climate change. The approaches needed for tackling the economic impacts of resource scarcity and climate change are the same: moving away from a dependence on fossil-fuel energy sources. Whereas the implications of climate change have driven only slow policy responses, economic consequences tend to drive shorter-term action. We know from the historical record that when there are oil-price spikes, the economy begins to respond within a year. Governments that fail to plan for the decline in fossil-fuel production will be faced with potentially major blows to their economies even before rising sea levels flood their coasts or crops begin to fail catastrophically.

The solutions are not secret or mysterious. Globally we get $55 \times 10^{18}$ joules of useful energy from $475 \times 10^{18}$ joules of primary energy from fossil fuels, biomass and nuclear power plants. The difference is due to energy losses and inefficiencies in the conversion and transmission processes. By increasing the efficiency, we could get the same useful energy by burning less fuel. We need to specify conservation goals for improving the efficiency of use of fossil-fuel energy. These include taxing oil to keep prices high and to encourage a reduction in energy use; encouraging nuclear energy; questioning if and how economic growth can continue without an increase in fossil fuels; lowering speed limits on roads and encouraging public transport; or redirecting tax credits towards renewable-energy development. The transformation will take decades, so we must begin as soon as possible. Emphasizing the short-term economic imperative from oil prices must be enough to push governments into action now.

James Murray is in the School of Oceanography, University of Washington, Seattle, Washington 98195, USA. He was founding director of the University of Washington's Program on Climate Change. David King is director of the Smith School of Enterprise and the Environment, University of Oxford, Oxford OX12BQ, UK, and senior science adviser to the bank UBS. He served as chief scientific adviser to the UK government in 2000-07.

e-mail:jmurray@u.washington.edu

1. Hirsch, R. L., Bezdek, R. \& Wendling, R. Peaking of World Oil Production: Impacts, Mitigation, \& Risk Management (US Department of Energy, 2005).

2. US Energy Information Administration Annual Energy Outlook 2011 (DOE/EIA, 2011).

3. Owen, N. A., Inderwildi, O. R. \& King, D. A Energy Policy 38, 4743-4749 (2010).

4. Cambridge Energy Research Associates Finding the Critical Numbers: What Are the Real Decline Rates for Global Oil Production? (IHS/CERA, 2007)

5. International Energy Agency World Energy Outlook 2008 (IEA, 2008).

6. Canadian Association of Petroleum Producers Report of the Dialogues on the Oil Sands (CAPP, 2011).

7. Hirsch, R. L., Bezdek, R. H. \& Wendling, R. M. The Impending World Energy Mess: What it is and What it Means to You! (Apogee Prime Press, 2010).

8. Energy Watch Group Coal: Resources and Future Production, EWG-Series No. 1/2007 (EWG, 2007).

9. World Energy Council 2010 Survey of Energy Resources (WEC, 2010)

10. Rutledge, D. Int. J. Coal Geol. 85, 23-33 (2011)

11. National Research Council Coal: Research and Development to Support National Energy Policy (National Academies Press, 2007).

12. Hughes, D. Will Natural Gas Fuel America in the 21st Century? (Post Carbon Institute, 2011).

13. Hamilton, J. D. Causes and Consequences of the Oil Shock of 2007-08. Brookings Papers on Economic Activity. 215-259 (2009). 